\title{
Formation of Nitrogen Mono Oxide (NO) during Iron Ore Sintering Process
}

\author{
Wei $\mathrm{LV}^{1)}$ Xiaohui FAN, ${ }^{1)}$ Xiaobo MIN, ${ }^{2,3) *}$ Min $\mathrm{GAN}^{, 1}$ Xuling $\mathrm{CHEN}^{1)}$ and Zhiyun $\mathrm{J}^{11}$ \\ 1) School of Minerals Processing and Bioengineering, Central South University, Changsha, Hunan, 410083 PR China. \\ 2) Department of Environmental Engineering, School of Metallurgy and Environment, Central South University, Changsha, \\ 410083 China. \\ 3) Chinese National Engineering Research Centre for Control and Treatment of Heavy Metal Pollution, Changsha, 410083 \\ China.
}

(Received on June 28, 2017; accepted on October 19, 2017; J-STAGE Advance published date: December 21, 2017)

\begin{abstract}
The effects of mineral phases evolution and atmosphere transition on the transformation of fuel-N during sintering process were studied in this paper. With the temperature increasing, the conversion rate of fuel-N to NO decreased as the coke was burning in the granules, due to the effect of sintering materials. This presented the contrary law compared with the fuel burning alone. As coke burnt at temperature below $1000^{\circ} \mathrm{C}$, it was mainly the oxidizing reaction between fuel- $\mathrm{N}$ and oxygen. Iron ores and fluxes getting in touch with coke could promote the oxidation of fuel-N that converts to NO. While the temperature increased to higher than $1000^{\circ} \mathrm{C}$, the gasification reaction between carbon and $\mathrm{CO}_{2}$ occurred apparently and generated $\mathrm{CO}$. There was a competition between fuel-N's oxidation and NO's reduction. Meanwhile, iron oxide and calcium ferrite (CF) had a catalytic effect on NO-CO reduction reaction. Particularly, the CF generated at high temperature had the most significant catalytic activity. As a consequence, the transformation of fuel-N was inhibited, making $\mathrm{NO}$ emission less at higher temperature.
\end{abstract}

KEY WORDS: iron ore sintering; NO formation; fuel-N oxidation; NO reduction.

\section{Introduction}

Nitrogen oxides, smoke dust and sulfur dioxide are three major air pollutants. NOx is not only an important factor to form acid rain, mist and photochemical smog, but also an significant precursor of fine particles (PM2.5). ${ }^{1,2)}$ Iron and steel enterprise is one of the major source of NOx emissions, accounting for more than $10 \%$ of the total NOx emissions by report. Peculiarly, NOx emitted from sintering process accounts for more than $50 \%$ of the total emissions of iron and steel plants. ${ }^{3)}$

NOx in the sintering process is mainly the fuel-NOx, usually generated by fuel-N's transformation in the burning process of coke breeze or anthracite, among which about $98 \%$ is NO. ${ }^{4)}$ Meanwhile, if there is a reducing atmosphere and appropriate catalyst, $\mathrm{NO}$ can be reduced to $\mathrm{N}_{2}$ or other NOx with low valence. The total emission of NOx ultimately depends on the oxidation of fuel-N and the reduction of NO. ${ }^{5-8)}$ The research of NOx's generation and discharge in sintering process has drawn much attention in recent years. Studies have shown that sintering parameters such as water ratio, fuel ratio, quicklime ratio and the thickness of bed layer had important influences on the NOx concentration in flue gas. ${ }^{9)}$ Mineral elements like $\mathrm{Fe}$ and $\mathrm{Ca}$ could

\footnotetext{
* Corresponding author: E-mail: mxb@csu.edu.cn

DOI: http://dx.doi.org/10.2355/isijinternational.ISIJINT-2017-370
}

accelerate the separation of fuel-N to form $\mathrm{NO}$, while $\mathrm{Mg}$ had an opposite effect. Si and Al could hardly effect the thermal migration of fuel-N. ${ }^{10-13)}$ The researches of Liang $\mathrm{H}$ and $\mathrm{Xu} \mathrm{C}$. $\mathrm{B}$ both indicated that $\mathrm{Fe}_{2} \mathrm{O}_{3}$ showed a reactivity to the removal of $\mathrm{NO}$ in the $\mathrm{NO} \mathrm{NO}-\mathrm{CO}-\mathrm{CO}_{2}-\mathrm{N}_{2}$ system. ${ }^{14,15)}$ $\mathrm{K}$. Monticelli and Min Gan found that the calcium ferrite generated in the sintering process played a significant role in promoting the reaction between $\mathrm{CO}$ and NOx. $\mathrm{K}$. Katayama believed the calcium ferrite formed by chemical reaction between adherent $\mathrm{CaO}$ on coke breeze surface and fine iron ore had effect on inhibiting NOx emission. The effect increased with the increasing of reaction temperature and decreasing of atmospheric oxygen potential. ${ }^{16-18)} \mathrm{D}$. Hirabayashi believed in the combustion system, a highly active superoxide radical $\left(\mathrm{O}_{2}{ }^{-}\right)$could be formed on the surface of calcium ferrites and the atmospheric oxygen strongly affected the equilibrium formation of such oxygen adspecies. $^{19)}$

Sintering process is characterized by high temperature, uneven atmosphere and complex chemical reactions with multi element and multiphase. The burning environment of solid fuel is quite complicated. Sintering materials mainly compose of iron ores, fluxes and fuels, the chemical compositions are mainly $\mathrm{Fe}_{2} \mathrm{O}_{3}, \mathrm{Fe}_{3} \mathrm{O}_{4}, \mathrm{CaO}$ and $\mathrm{C}$. Moreover, series compounds are generated by high temperature process, such as calcium ferrite like $\mathrm{CaO} \cdot \mathrm{Fe}_{2} \mathrm{O}_{3}$, $2 \mathrm{CaO} \cdot \mathrm{Fe}_{2} \mathrm{O}_{3}$, and $\mathrm{CaO} \cdot 2 \mathrm{Fe}_{2} \mathrm{O}_{3}$ as well as silicate com- 
pounds like $\mathrm{CaO} \cdot \mathrm{FeO} \cdot \mathrm{SiO}_{2}$ and $2 \mathrm{FeO} \cdot \mathrm{SiO}_{2} \cdot{ }^{20-22)}$ When the basicity increases to 2.0 and above, calcium ferrite is the main binder phase. ${ }^{23)}$ Thus, fuel is wrapped or adhered by iron ore and flux in sintering process, which makes the combustion condition very different from the one that fuel burns alone. Because the contact composition of fuel is multivariate and will change with temperature increasing, the conversion of fuel-N will be effected. The study of this aspect is insufficient at present. In this paper, the mineral phases evolution and atmosphere transition were studied, based on the research, their effects mechanism on fuel-N's transformation during sintering process were revealed. The results of this study has an important significance to reduce NOx emissions during sintering process.

\section{Materials and Methods}

\subsection{Materials}

The chemical components of raw materials are shown in Table 1. The TFe content of hematite and magnetite were $66.98 \mathrm{wt} \%$ and $67.41 \mathrm{wt} \%$, the $\mathrm{FeO}$ content were $0.25 \mathrm{wt} \%$ and $27.72 \mathrm{wt} \%$, respectively. Besides a few $\mathrm{SiO}_{2}$, there were little other component, indicating that they were relatively pure and typical iron ores. The proportions of raw materials are in Table 1 when basicity was 2.0.

Coke breeze was used as solid fuel. The industrial analysis is shown in Table 2. The content of fixed carbon and volatile were $85.10 \mathrm{wt} \%$ and $2.2 \mathrm{wt} \%$, respectively. The fuel-N content was $0.91 \mathrm{wt} \%$.

$\mathrm{CaO} \cdot \mathrm{Fe}_{2} \mathrm{O}_{3}, 2 \mathrm{CaO} \cdot \mathrm{Fe}_{2} \mathrm{O}_{3}$ and $\mathrm{CaO} \cdot 2 \mathrm{Fe}_{2} \mathrm{O}_{3}$ (abbreviated as $\mathrm{CF}, 2 \mathrm{CF}$ and $\mathrm{C} 2 \mathrm{~F}$ ) were synthesized from analytical reagent grade $\mathrm{Fe}_{2} \mathrm{O}_{3}$ and $\mathrm{CaO}$. The chemical reagents were fully mixed according to theoretical proportion of compounds and put into a corundum boat. The mixture was heated for $60 \mathrm{~min}$ in the muffle furnace programmed to $1250^{\circ} \mathrm{C}-1350^{\circ} \mathrm{C}$. Then the products were cooled to room temperature and grinded. The samples of products were

Table 1. The chemical components and ignition loss of raw materials $/ w t \%$.

\begin{tabular}{cccccccccc}
\hline \multirow{2}{*}{$\begin{array}{c}\text { Mine } \\
\text { types }\end{array}$} & \multicolumn{7}{c}{ Chemical components } & & \\
\cline { 2 - 7 } & $\mathrm{TFe}$ & $\mathrm{FeO}$ & $\mathrm{SiO}_{2}$ & $\mathrm{CaO}$ & $\mathrm{MgO}$ & $\mathrm{Al}_{2} \mathrm{O}_{3}$ & & \\
\hline Hematite & 66.98 & 0.25 & 3.62 & 0.10 & 0.06 & 0.63 & 0.76 & 23.01 \\
Magnetite & 67.41 & 27.72 & 5.03 & 0.09 & 0.45 & 1.05 & 1.55 & 12.39 \\
Limonite & 57.76 & 0.21 & 5.40 & 0.30 & 0.48 & 1.45 & 7.92 & 23.60 \\
Dolomite & 0.23 & - & 0.10 & 33.66 & 19.56 & 0.12 & 45.97 & 4.59 \\
$\begin{array}{c}\text { Limestone } \\
\text { Quicklime }\end{array}$ & 1.70 & 0.09 & 1.80 & 50.04 & 3.38 & 0.21 & 42.29 & 7.60 \\
$\begin{array}{c}\text { Coke } \\
\text { breeze }\end{array}$ & 0.85 & 0.12 & 1.03 & 84.55 & 0.33 & 0.72 & 10.00 & 1.50 \\
$\begin{array}{c}\text { Return } \\
\text { fine }\end{array}$ & 57.00 & 6.50 & 4.96 & 8.28 & 1.50 & 1.47 & 0.11 & 23.00 \\
\hline
\end{tabular}

analyzed by X-ray diffraction (XRD, Rigaku D/max-2500). It was regarded as qualified when the content of target compound reaching to more than $90 \%$.

Standard gas of oxygen and argon were used in the tests, the purity was $99.999 \%$. The NO standard gas with concentration $5000 \mathrm{ppm}$ and $\mathrm{CO}$ standard gas with concentration $10000 \mathrm{ppm}$ were used, and their balance gas was argon.

\subsection{Methods}

2.2.1. Methods for Researching NOx Formation Behavior

The combustion experiment was conducted in a vertical furnace, of which the hearth could be programmed to target temperature. A heating resisting quartz tube with $\Phi 38 \times 70 \mathrm{~mm}$ was used as reactor, as shown in Fig. 1 . Samples were put into at the top of the tube and placed in a porous gasket, while gases went through the sample layer from the bottom of the tube. Flue gas analyzer (Germany MRU company, MGA5) was used to analyze the gas composition during the whole process.

Before test, $30 \mathrm{~g}$ quartz sand with $3 \mathrm{~mm}$ was put on the gasket in advance to prevent the leak of fine particles. The hematite, magnetite, quicklime and $\mathrm{CF}, 2 \mathrm{CF}$ and $\mathrm{C} 2 \mathrm{~F}$ were grinded to $-0.5 \mathrm{~mm}$. The coke breeze was screened to 1-2 $\mathrm{mm}$. In order to study the effect of sintering materials on NO generation, $2.00 \mathrm{~g}$ coke breeze was mixed directly with $0.50 \mathrm{~g}$ hematite, magnetite, quicklime, $\mathrm{CF}, 2 \mathrm{CF}$ and $\mathrm{C} 2 \mathrm{~F}$ in each group, respectively. When came to simulate the combustion state of granules, $1.00 \mathrm{~g}$ coke breeze was blended with iron ores and fluxes as suitable ratio in each group (the proportion of each material is shown in Table $1)$, then add water and make granules with diameter about 5-8 mm. The balls were dried at $100^{\circ} \mathrm{C}$ in the oven over 8 hours. After drying, the balls had a certain strength to prevent the fracture when loading into the reactor. $21 \%$ oxygen and $79 \%$ argon gas were injected in, the total flow was $0.6 \mathrm{~m}^{3} / \mathrm{h}$ (the air was excess according to the oxygen content in the tail gas). The furnace was programmed to the target temperature at $0.5^{\circ} \mathrm{C} / \mathrm{s}$. The reactor was put into the furnace after achieving the set temperature.

The evaluation index of fuel-N's transformation mainly

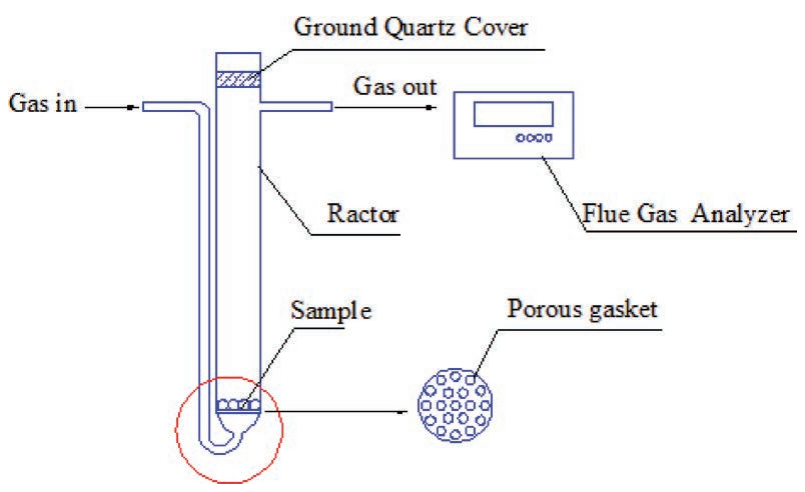

Fig. 1. Diagrammatic drawing of the reactor. (Online version in color.)

*LOI: Loss of ignition

Table 2. Industrial analysis of coke breeze (dry base).

\begin{tabular}{cccccc}
\hline Fuel & Ash content $/ w t \%$ & Volatile content $/ w t \%$ & Fixed carbon/wt $\%$ & Calorific value/MJ·kg-1 & Fuel-N content $/ w t \%$ \\
\hline Coke breeze & 12.70 & 2.20 & 85.10 & 27.40 & 0.91 \\
\hline
\end{tabular}


involved the real-time NOx concentration and fuel-N's conversion rate. Only part of fuel-N transformed into NOx during combustion. As reported previously, ${ }^{24)}$ the fuel-N's conversion rate $\eta_{\mathrm{N}}$ was defined as the ratio of the mass of fuel-N convert to $\mathrm{NO}$ and the quality of $\mathrm{N}$ in fuel. The conversion rate was calculated according to the NOx concentration as follows:

$$
\begin{gathered}
\eta_{N}=\left(\frac{[N]_{a}}{[N]_{0}}\right) \times 100 \% \ldots \ldots . . . \\
{[N]_{a}=625 \int_{t_{s}}^{t_{e}} C(N O) \times Q_{\text {gas }}^{t} d_{t}} \\
{[N]_{0}=a\left(\text { Fuel }_{N}\right) \times m \times 1000 .}
\end{gathered}
$$

Where, $\eta_{\mathrm{N}}$ is the conversion rate of fuel-N (\%), $[\mathrm{N}]_{\mathrm{a}}$ is the mass of fuel-N converted to $\mathrm{NO}(\mathrm{mg}), \mathrm{C}(\mathrm{NO})$ is volume concentration of $\mathrm{NO}(\%), \mathrm{Q}_{\mathrm{gas}}^{\mathrm{t}}$ is the inlet flow at standard state $(\mathrm{L} / \mathrm{min}), 625$ is the quantity of $\mathrm{N}$ in the unit volume of $\mathrm{NO}$ at standard state $(\mathrm{mg} / \mathrm{L}),[\mathrm{N}]_{0}$ is the quantity of $\mathrm{N}$ in the fuel $(\mathrm{mg}), \mathrm{m}$ is the mass of fuel $(\mathrm{mg}), a\left(\mathrm{Fuel}_{N}\right)$ is the content of fuel-N in coke breeze. The integral value was automatically calculated by the software (Origin Pro 8.5).

\subsubsection{Methods of Reduction between $\mathrm{NO}$ and $\mathrm{CO}$}

When it came to the reaction of $\mathrm{CO}-\mathrm{NO}$, quartz tube showed in Fig. 1 was used as reactor. Hematite, magnetite and CF were grinded to $-0.5 \mathrm{~mm}$ and weighed $0.50 \mathrm{~g}$ respectively in each run of the test. Then dispersed by $30 \mathrm{~g}$ pure quartz sand with size of $0.5-1 \mathrm{~mm}$ in each run of the test. The sample was put onto the porous gasket and protected by argon. The furnace was programmed to the target temperature at $0.5^{\circ} \mathrm{C} / \mathrm{s}$. Then inlet standard gas of Ar, NO and $\mathrm{CO}$ from the bottom of the tube. The total flow was $1.0 \mathrm{~L} / \mathrm{min}$, the initial concentration of NO was $500 \mathrm{ppm}$. The gas went through the sample layer and discharged from the top of the tube. Flue gas analyzer was used to analyze the export concentration of gas. The degradation of NO in a certain time was calculated as the following formula:

$$
\eta_{N O}=\left(C_{i}-C_{o}\right) / C_{i} \times 100 \%
$$

Where, $\eta_{\mathrm{NO}}$ is the degradation of NO (\%), $C_{i}$ is the initial concentration of NO (ppm), $C_{o}$ is the export concentration of NO (ppm). used to analyze the gas composition during the whole process.

\subsubsection{Tests of Fuel's Reactivity}

The non-isothermal gasification reaction of coke breeze was used to study its reactivity (reaction between $\mathrm{CO}_{2}$ and C) by the Synchronous heat analyzer (NETZSCH STA $449 \mathrm{C}$, German). The gas flow velocity of $\mathrm{CO}_{2}$ was controlled $0.5 \mathrm{~m} / \mathrm{s}$, the rate of temperature increasing was $15^{\circ} \mathrm{C} / \mathrm{min}$.

The isothermal gasification reaction of coke breeze was studied in the vertical furnace. The cup for placing sample was put into the quartz tube when the temperature reached to the target. There was $25 \mathrm{~g}$ dried fuel with size of $3 \mathrm{~mm}$ in the cup. The flow of $\mathrm{CO}_{2}$ was $10 \mathrm{~L} / \mathrm{min}$. The weight was tested and recorded by electronic balance and computer respectively, and the system read the data every $20 \mathrm{~s}$ until the weightlessness stayed constant. Thus the gasification conversion rate $\left(x_{c}\right)$ was calculated according to the weight loss value of each time. The formula are as followed:

$$
x_{c}=\left(1-\frac{m}{m_{0}}\right) \times 100 \%
$$

Where, $x_{\mathrm{c}}$ is the gasification conversion rate $(\%), \mathrm{m}_{0}$ is the initial mass $(\mathrm{g}), \mathrm{m}$ is the mass after the reaction $(\mathrm{g})$.

\subsubsection{Methods for Micro Sintering Simulating Experi- ment}

The generation of calcium ferrite at different temperatures was studied by micro sintering simulating experiment. The schematic diagram of test device was shown in Fig. 2. Before test, screen out the fraction of $-0.5 \mathrm{~mm}$ in the iron ores. Fine-grained iron ores and fluxes were blended according to the proportion showed in Table 1. Then the mixture were grinded into $-0.074 \mathrm{~mm}$. Some water was added to make columniform briquettes with $\Phi 10 \times 10 \mathrm{~mm}$ in a stamper. The briquettes was dried in the oven and then was placed in an alundum porcelain boat with multiple holes on both sides to ensure ventilation. Roasting process was conducted in a horizontal furnace which could be programmed to the target temperature. $\mathrm{N}_{2}$ and $\mathrm{O}_{2}$ were injected to simulate the air atmosphere. The total flow during the test was $0.35 \mathrm{~m}^{3} / \mathrm{h}$.

The products of micro sintering were mounted with epoxy

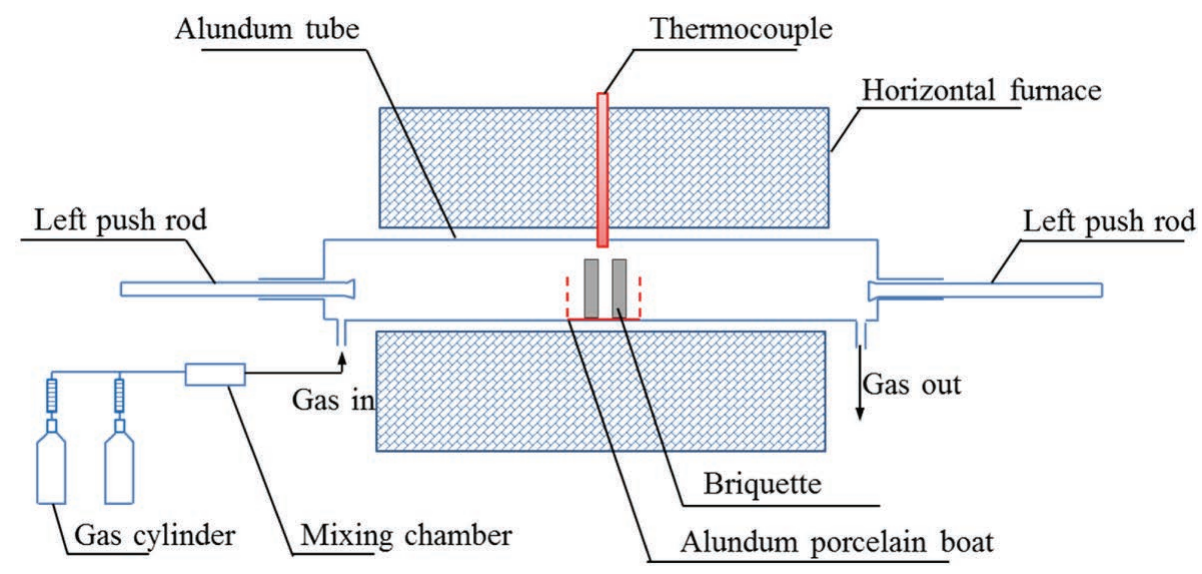

Fig. 2. Schematic diagram of micro sintering test device. (Online version in color.) 
resin, and then polished to form a section. Then the microstructures of them were observed by optical microscope (Leica DMRXE), and mineral components were detected by image analysis software (Qwin). ${ }^{21)} 400$ viewsheds were selected evenly on the surface of polished section under the vision of 200 times with $0.5 \mathrm{~mm}$ as sampling step. In every viewshed, the mineral contents were analyzed by identifying the grayscale of different minerals using Qwin software. The content of CF in this study was expressed as area ratio.

\section{Results and Discussion}

\subsection{Experimental Results of Fuel-N Transformation}

\subsubsection{Basic Laws of NO Generation of Sintering Mixture}

The generation behaviors of NO when burning sinter mixture (fuel contained in the granule) and single coke breeze were comparatively studied. The results are shown in Figs. 3 and 4. It can be inferred from Figs. 3(a) and 4(a) that in both experiments, the emission rate of $\mathrm{NO}$ was accelerated with the increase of temperature, so as the peak value of NO concentration. Compared with heating single coke breeze, the emission rate of NO from heating the granules was slower, but with an extended release time. Take burning at $1000^{\circ} \mathrm{C}$ as example, the burn-off time of heating single coke breeze was $7 \mathrm{~min}$, while the one was $10 \mathrm{~min}$ for heating granules. Mechanism about these phenomena will be further discussed in section 3.2.1.

It was obvious in Figs. 3(b) and 4(b) that the conversion rate of fuel-N was increased as the temperature increasing when heating single coke breeze. On the contrary, the conversion rate of fuel-N when heating granules was decreased with the increase of temperature. Moreover, at the same temperature, the conversion rate of fuel-N was higher when heating granules.

\subsubsection{Phase Transition and Change of Combustion Condi- tions in Sintering Process}

In sintering process, fuels are surrounded by multicomponent materials, such as hematite, magnetite and fluxes, in sintering process. In addition, new compounds can generate from solid phase reaction and liquid phase formation during high temperature process. Therefore, the combustion conditions of fuel in sintering vary a lot in different temperature ranges. Calcium ferrite is the main liquid bonding phase of sinter, solid-phase reaction between $\mathrm{Fe}_{2} \mathrm{O}_{3}$ and $\mathrm{CaO}$ occurs at about $500^{\circ} \mathrm{C}$ to $700^{\circ} \mathrm{C}$. The reaction rate is quite slow at such temperature range, however, the reaction ate can be greatly accelerated by increasing temperature. ${ }^{20)}$ Figure 5 shows the generation of calcium ferrite at different temperatures by micro sintering simulating experiments. The content of calcium ferrite was $18.10 \%$ and $42.09 \%$ at $900^{\circ} \mathrm{C}$ and $1000^{\circ} \mathrm{C}$, respectively, which was further increased to over $60 \%$ when the temperature was higher than $1100^{\circ} \mathrm{C}$. It indicated that a large amount of calcium ferrite started to generate around fuel when temperature reaching above $1000^{\circ} \mathrm{C}$.
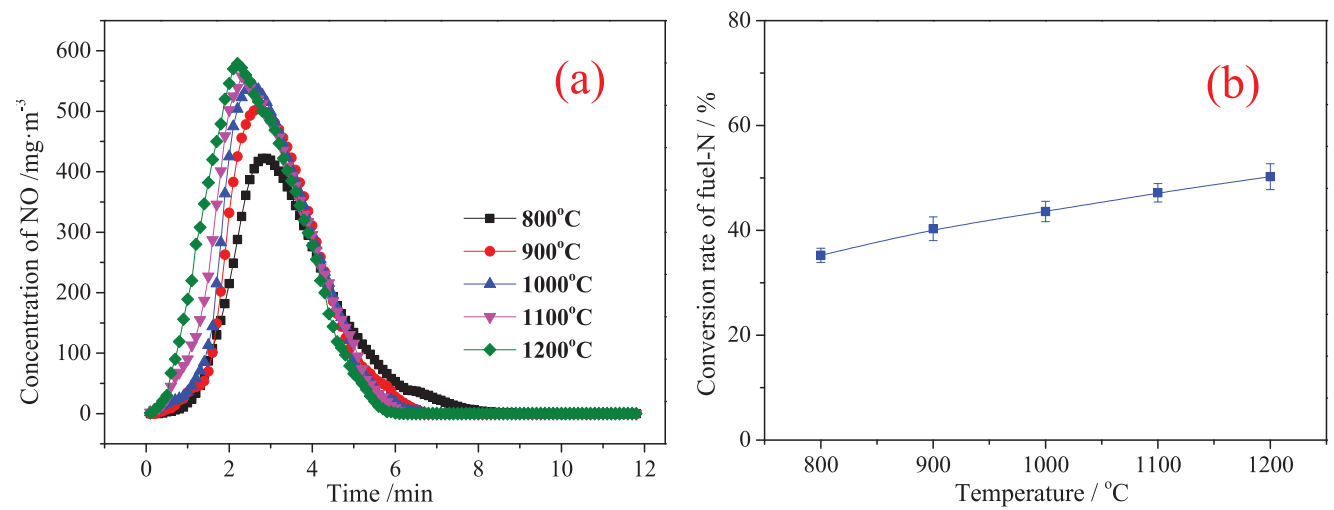

Fig. 3. Effects of heating temperature on NO concentrations and conversion rate of fuel-N when single coke breeze burning. (Online version in color.)
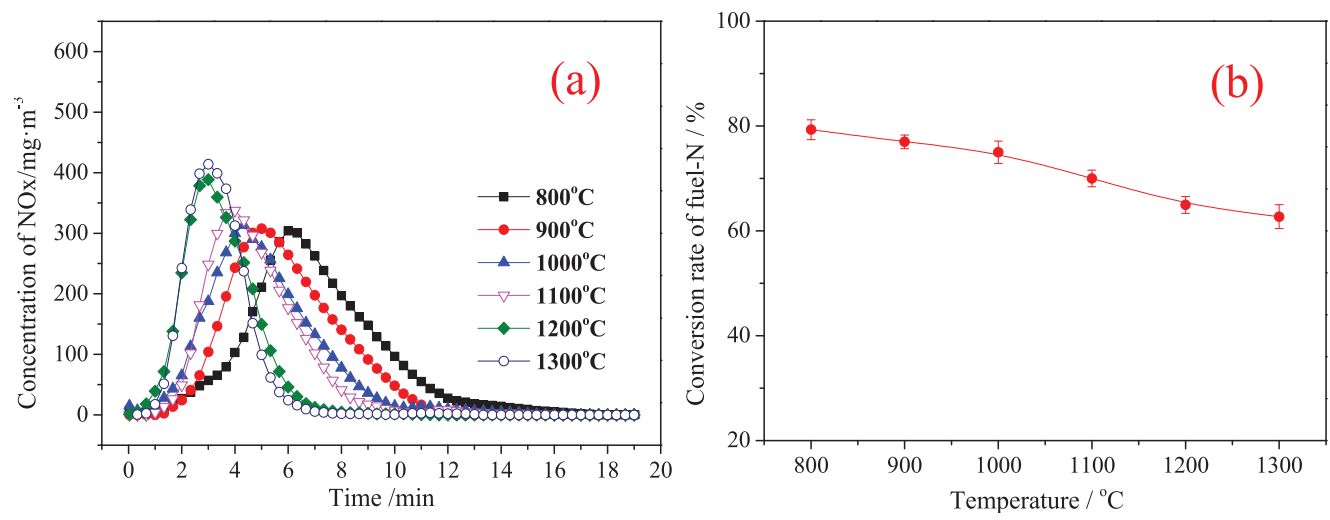

Fig. 4. Effect of heating temperature on $\mathrm{NO}$ concentrations and conversion rate of fuel-N when heating granules. (Online version in color.) 
In addition to the surrounding material, the combustion atmosphere also has an important influence on the burning of fuel. ${ }^{25)}$ For $\mathrm{C}$ in sintering process, there are the combustion reactions $\left(2 \mathrm{C}+\mathrm{O}_{2} \rightarrow 2 \mathrm{CO}\right.$ and $\left.\mathrm{C}+\mathrm{O}_{2} \rightarrow \mathrm{CO}_{2}\right)$ and the gasification reaction $\left(\mathrm{C}+\mathrm{CO}_{2} \rightarrow 2 \mathrm{CO}\right)$. From the non-isothermal gasification thermogravimetric curve (Fig. 6(a)), it was known that the reaction between $\mathrm{C}$ and $\mathrm{CO}_{2}$ to generate $\mathrm{CO}$ started at $826^{\circ} \mathrm{C}$ and ended at $1205^{\circ} \mathrm{C}$. The reaction rate reached the maximum around $1100^{\circ} \mathrm{C}$, which was $4.01 \% / \mathrm{min}$. The isothermal gasification curve is shown in Fig. 6(b). It was clear that the reaction was speeded up with the increase of temperature and it cost less time when the $x_{c}$ reached to $50 \%$. Therefore, the higher the temperature was, the more violent gasification reaction of $\mathrm{C}$ was, which was conducive to generating $\mathrm{CO}$ and intensified the reducing atmosphere.

Accordingly, it can be summarized form Figs. 5 and 6 that combustion conditions of fuel changed a lot in different

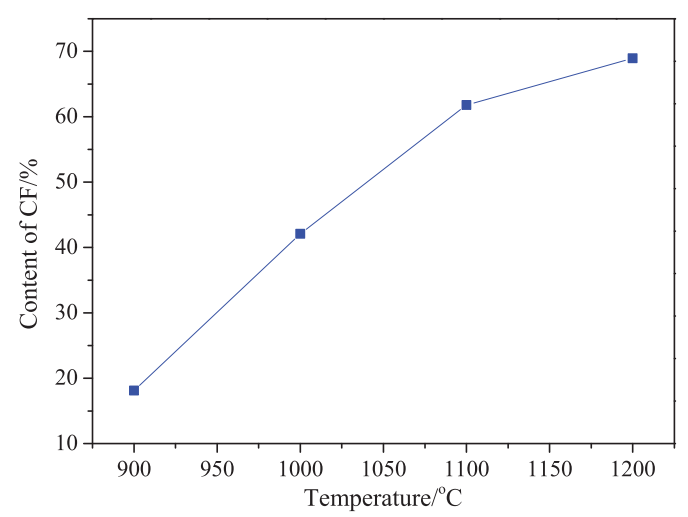

Fig. 5. Calcium ferrite content of different temperature. (Online version in color.)

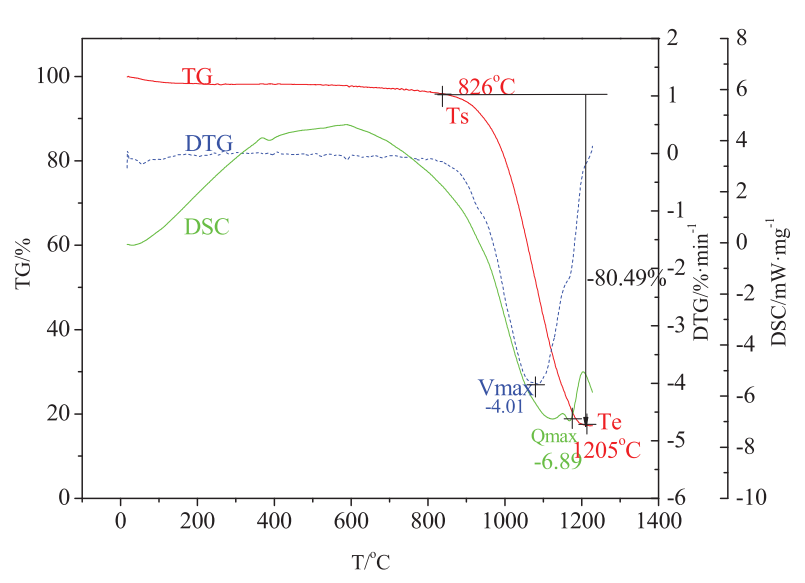

(a) Non-isothermal gasification of coke breeze temperature range, which is listed in Table 3. Coke can burn at the temperature above $700^{\circ} \mathrm{C}$. In the preliminary stage of combustion, at about $700^{\circ} \mathrm{C}$ to $1000^{\circ} \mathrm{C}$, the substances contacted to fuel is mainly raw material of sintering, such as hematite, magnetite and fluxes. Coke breeze reacts with $\mathrm{O}_{2}$ and mainly generates $\mathrm{CO}_{2}$. As the temperature increasing gradually, the amount of calcium ferrite increases and gasification reaction of coke breeze becomes violent, making the $\mathrm{CO}$ content increases as well.

\subsubsection{The Effect of Raw Materials on NO Generation Behavior}

When the temperature is not higher than $1000^{\circ} \mathrm{C}$, before the quantitative formation of calcium ferrite, the substances surrounding fuels are mainly hematite, magnetite, quicklime, etc. Their effects on the conversion rate of fuel-N during the combustion process were studied at $1000^{\circ} \mathrm{C}$. The results are shown in Fig. 7. It was shown that hematite, mag-

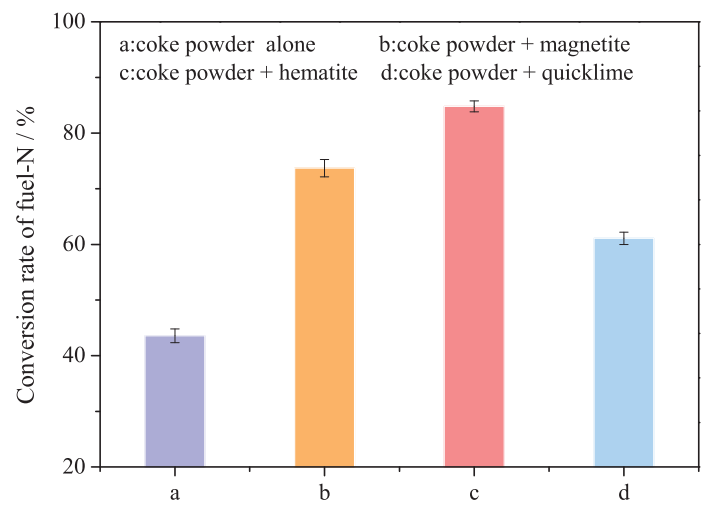

Fig. 7. The effect of raw materials on the conversion of fuel-N in burning process. (Online version in color.)

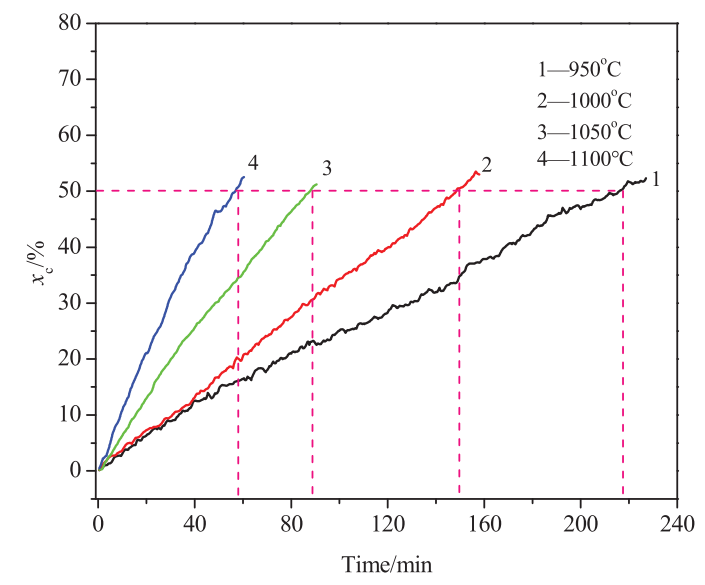

(b)Isothermal gasification of coke breeze

Fig. 6. Combustion and gasification reaction of coke breeze. (Online version in color.)

Table 3. Changes of combustion conditions at different temperature ranges.

\begin{tabular}{|c|c|c|c|c|c|c|c|}
\hline \multirow{2}{*}{$\begin{array}{l}\text { Temperature } \\
\text { interval } /{ }^{\circ} \mathrm{C}\end{array}$} & \multicolumn{3}{|c|}{ Atmosphere } & \multicolumn{4}{|c|}{ Substances contacted to fuel } \\
\hline & $\mathrm{O}_{2}$ & $\mathrm{CO}_{2}$ & $\mathrm{CO}$ & $\mathrm{Fe}_{2} \mathrm{O}_{3}$ & $\mathrm{Fe}_{3} \mathrm{O}_{4}$ & $\mathrm{CaO}$ & $\mathrm{CF}$ \\
\hline $700-1000$ & In quantity & Generate in quantity & A little & In quantity & A few & A few & A few \\
\hline $1000-1100$ & In quantity & Decrease & Increase & Decrease & Decrease & Decrease & Increase \\
\hline $1100-1200$ & In quantity & Decrease & Increase & Decrease & Decrease & Decrease & Generate in quantity \\
\hline
\end{tabular}


netite and quicklime could promote the conversion of fuel-N to NO, among which the hematite's effect was more significant than that of the others. The conversion rate of fuel-N was $43.57 \%$ when coke breeze burning alone, it increased to $73.70 \%$ and $84.83 \%$ when magnetite and hematite were added, respectively.

\subsubsection{The Effect of Calcium Ferrite on NO Generation Behavior}

Calcium ferrite starts to generate rapidly at $1000^{\circ} \mathrm{C}$ to $1200^{\circ} \mathrm{C}$. The effect of CF on the fuel-N's conversion at such temperature range was studied. The results are shown in Fig. 8. Increasing the temperature from $1000^{\circ} \mathrm{C}$ to $1200^{\circ} \mathrm{C}$, the conversion rate of fuel-N was decreased from $40.71 \%$ to $30.71 \%$. Therefore, higher temperature contributed to the inhibitory effect of $\mathrm{CF}$ on the conversion rate of fuel-N.

Effects of three types of calcium ferrites were also studied at $1000^{\circ} \mathrm{C}$. The fuel-N's conversion rate is shown in Fig. 9. Clearly, when adding these calcium ferrites, the conversion rates of fuel-N were all decreased compared with the fuel-N burning alone. Specially, the highest decreasing degree of conversion rate was achieved by $2 \mathrm{CF}$, followed by $\mathrm{CF}$ and $\mathrm{C} 2 \mathrm{~F}$.

\subsection{Discussion of Conversion Mechanism of Fuel-N}

3.2.1. The System of Fuel Burning Process

Figure 10 shows the schematic diagram of fuel-N's con-

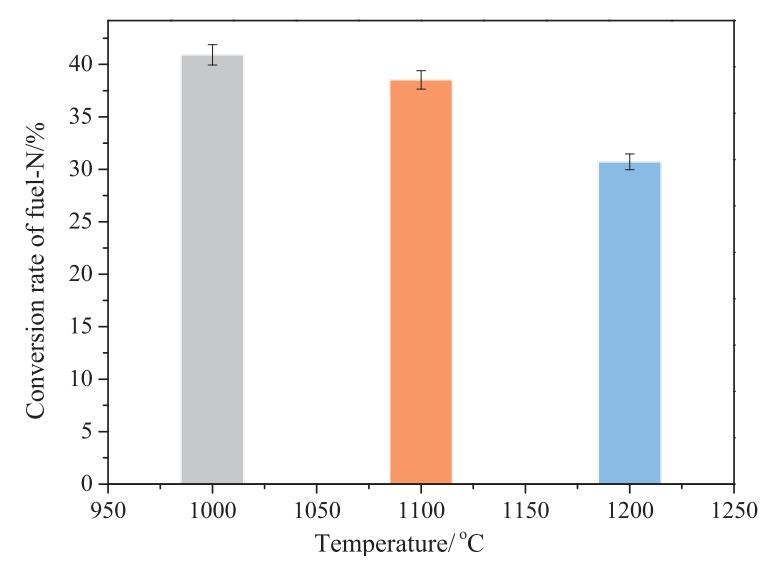

Fig. 8. The effect of $\mathrm{CF}$ on the conversion of fuel-N at different temperature. (Online version in color.) version and NO's generation during the process of heating granule.

The combustion process of $\mathrm{C}$ in the air is multiphase. Generally, it mainly goes through the following stages:

(1) Oxygen diffuses to the surface of the solid fuel,

(2) Oxygen reacts with fuel on the surface to form the product,

(3) The product diffuses from the surface to the gas phase.

As shown in Fig. 10, in sintering process, most of the coke breeze is in granules and surrounded by iron ores and fluxes. The coke breeze was wrapped by the raw materials and formed the parcel layer. Therefore, $\mathrm{O}_{2}$ has to go through the material layer to react with $\mathrm{C}$, suppressing diffusion $\left({ }^{*} 1\right)$ and reaction (1). The generated NO also has to go through the transfer process to discharge, suppressing diffusion $(* 2)$. So compared with coke combusts separately, the combustion speed of granules slows and the NO discharging time lengthens.

\subsubsection{The Effect of Raw Materials on CO-NO Reduction Reaction}

During the combustion of coke breeze, there exists oxidizing reaction of fuel-N: $\mathrm{C}(\mathrm{N})+\mathrm{C}(\mathrm{O}) \rightarrow \mathrm{C}(\mathrm{)})+\mathrm{C}(\mathrm{NO})$, among which $\mathrm{C}(\mathrm{)}) \mathrm{C}(\mathrm{N}), \mathrm{C}(\mathrm{NO})$ and $\mathrm{C}(\mathrm{O})$ represented the N, NO and $\mathrm{O}$ adsorbed on the surface of coke, respectively. Meantime, $\mathrm{NO}$ generated already can be reduced to $\mathrm{N}_{2}: 2 \mathrm{CO}+2 \mathrm{NO} \rightarrow \mathrm{N}_{2}+2 \mathrm{CO}_{2}$. The conversion rate of fuel-N

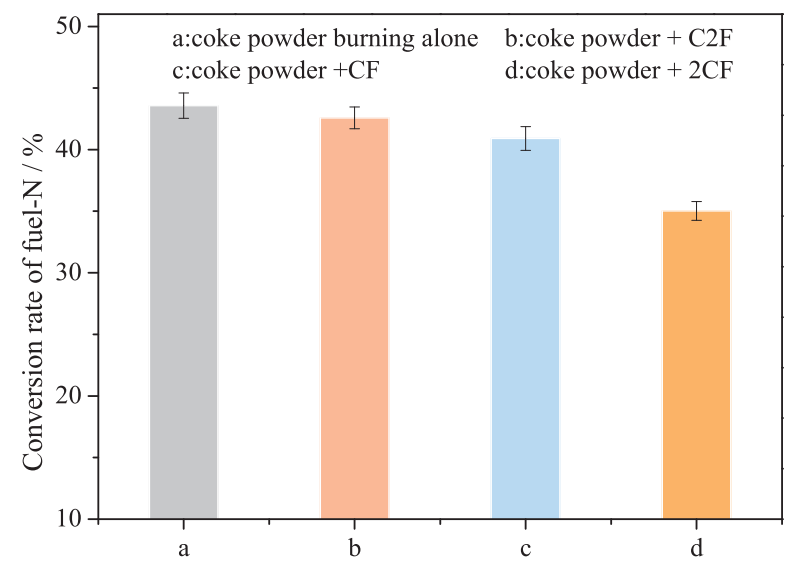

Fig. 9. The effect of calcium ferrite on the conversion rate of fuel$\mathrm{N}\left(1000^{\circ} \mathrm{C}\right)$. (Online version in color.)

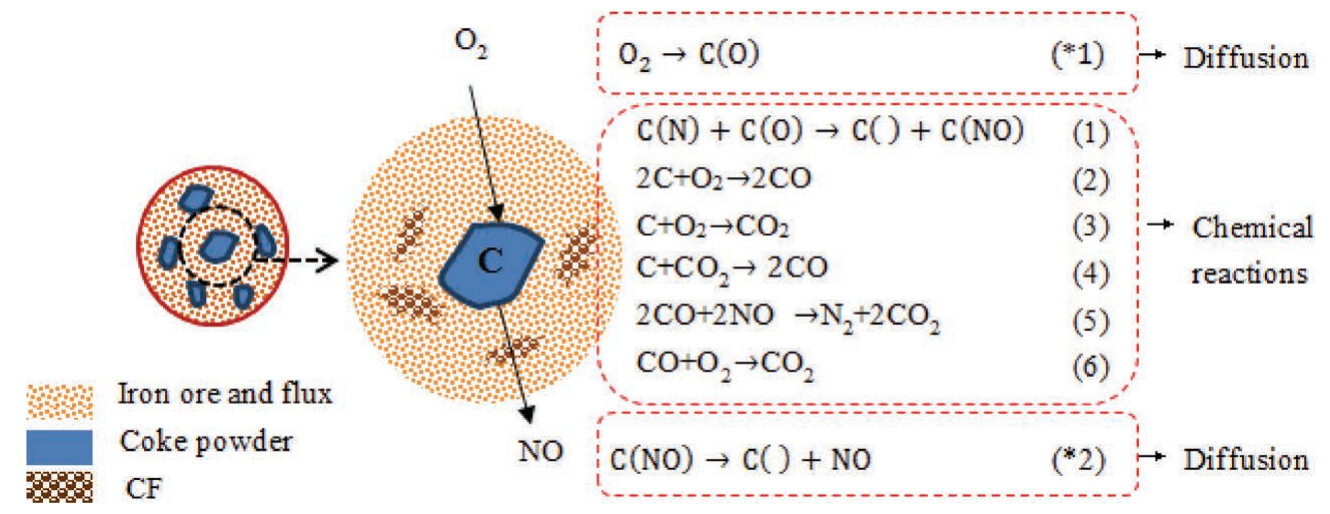

Fig. 10. Schematic diagram of fuel-N's conversion and NO's generation. (Online version in color.) 
depends on its oxidizing reaction and the reduction reaction of NO.

The effects of sintering materials on $\mathrm{CO}-\mathrm{NO}$ reaction were studied at $1000^{\circ} \mathrm{C}$. The initial concentration of $\mathrm{CO}$ was $1000 \mathrm{ppm}$. The results were shown in Fig. 11. The conversion rate of NO reduced with the extension of time and tended to be stable after a certain period of time. This was because on one hand, the catalytic reduction takes some time to proceed. On the other hand, the gas analyzer needs some time to response. Thus, the catalytic stability of materials was reflected by the stable conversion rate of NO. The CO-NO reaction was very slow without any catalyst and the NO degradation rate stayed less than $5 \%$ at $300 \mathrm{~s}$. Results demonstrated that hematite, magnetite and CF could all catalyze the $\mathrm{CO}-\mathrm{NO}$ reaction, since the speed of $\mathrm{CO}-\mathrm{NO}$ reaction was accelerated and the NO degradation rate was promoted when adding these minerals. The order of effect in magnitude was $\mathrm{CF}>$ hematite $>$ magnetite. It indicated that $\mathrm{CF}$ had a strong catalysis to the reduction of NO.

The effect of calcium ferrite to suppress the conversion of fuel-N is particularly significant. The catalysis of calcium ferrite on the CO-NO reaction was studied at different temperatures. The NO degradation rate was shown in Fig. 12. The degradation rate of $\mathrm{NO}$ increased as the temperature increasing. At $120 \mathrm{~s}$, the increased extent was little when

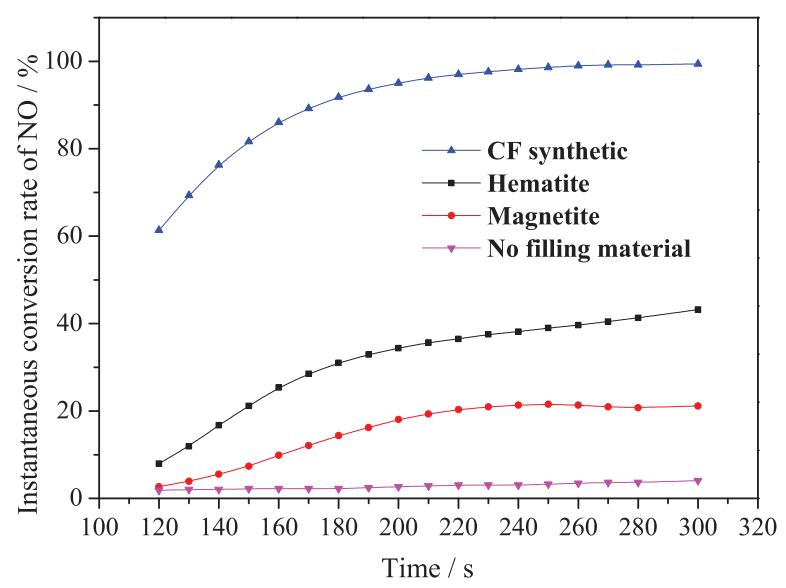

Fig. 11. The effects of sintering materials on $\mathrm{CO}-\mathrm{NO}$ reaction $\left(1000^{\circ} \mathrm{C}\right)$. (Online version in color.)

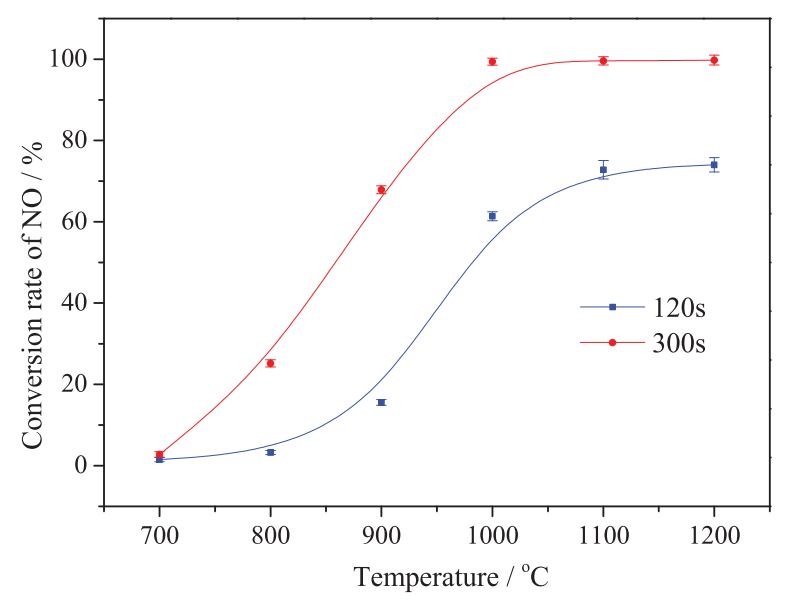

Fig. 12. The influence of temperature on the catalysis of CF. (Online version in color.) temperature rose from $700^{\circ} \mathrm{C}$ to $900^{\circ} \mathrm{C}$. At $900^{\circ} \mathrm{C}$, the $\mathrm{NO}$ degradation rate was only $15.55 \%$, while it was increased sharply to $61.55 \%$ when the temperature rose to $1000^{\circ} \mathrm{C}$. When temperature was higher than $1000^{\circ} \mathrm{C}$, the $\mathrm{NO}$ degradation rate reached to more than $99 \%$ and tended to be stable at $300 \mathrm{~s}$.

\subsubsection{Conversion Mechanism of Fuel-N at $700-1000^{\circ} \mathrm{C}$}

At the early stage of combustion, about $700^{\circ} \mathrm{C}$ to $1000^{\circ} \mathrm{C}$, the atmosphere in material layer was mainly oxidizing atmosphere. The calcium ferrite has not been generated in great quantity yet. Researches ${ }^{26)}$ had stated that $\mathrm{Fe}_{2} \mathrm{O}_{3}, \mathrm{Fe}_{3} \mathrm{O}_{4}$ and $\mathrm{CaO}$ could catalyze the combustion of coke, and the $\mathrm{Fe}_{2} \mathrm{O}_{3}$ 's effect was particularly obvious. At the same time, $\mathrm{Fe}_{2} \mathrm{O}_{3}$ and $\mathrm{Fe}_{3} \mathrm{O}_{4}$ would participate in the oxidizing reaction of fuel-N as intermediate. Therefore, before temperature reached to $1000^{\circ} \mathrm{C}$, the hematite, magnetite, quicklime, limestone etc. in raw materials promote the conversion of fuel-N to $\mathrm{NO}$ under oxidizing atmosphere. According to 3.1.2, the gasification reaction is weak and the generation of $\mathrm{CO}$ is minute, so the oxidizing atmosphere is primary at $700^{\circ} \mathrm{C}-1000^{\circ} \mathrm{C}$. In addition, the raw materials can promote the combustion process. Therefore, the generation of $\mathrm{NO}$ is superior at the preliminary combustion stage $\left(700^{\circ} \mathrm{C}-1000^{\circ} \mathrm{C}\right)$. As a result, at the same temperature, the conversion rate of fuel- $\mathrm{N}$ is higher when coke breeze burns in granules than in single state.

\subsubsection{Conversion Mechanism of Fuel-N Above $1000^{\circ} \mathrm{C}$}

When the temperature rises to $1000^{\circ} \mathrm{C}-1200^{\circ} \mathrm{C}$, according to 3.1.2, it can presume that the gasification reaction of coke (reaction (4)) gets violent and enhances the partial reducing atmosphere. On the other hand, the mass transfer of $\mathrm{O}_{2}$ is affected by the material layer. It is in favor of reaction (2) and adverse to reaction (3) in Fig. 10, making reducing atmosphere stronger on the surface of coke. At the same time, calcium ferrite begins to generate rapidly and quantitatively. Calcium ferrite can catalyze the reduction reaction between $\mathrm{CO}$ and NO. The discharge value of NO ultimately depends on the competition of oxidizing reaction of fuel-N and reduction reaction of NO. The reduction reaction of $\mathrm{NO}$ speeds up with the catalysis of calcium ferrite when $\mathrm{CO}$ exists in the atmosphere. The reduction of NO (reaction (5)) is promoted under such circumstance. That's why adding calcium ferrite can decrease the conversion rates of fuel-N. When temperature continues to rise, the iron ores and fluxes reduce and the calcium ferrite generates in quantity in the material layer. It is conductive to the reduction of NO. As a result, the conversion rate of fuel-N decreases with the temperature increasing when heating granules.

\section{Conclusions}

(1) The conversion rate of fuel-N increased with increasing the temperature when heating single coke breeze. On the contrary, the conversion rate of fuel-N decreased with the increasing of temperature when heating granules.

(2) At $700^{\circ} \mathrm{C}$ to $1000^{\circ} \mathrm{C}$, hematite, magnetite, quicklime, limestone etc. in raw materials promote the conversion of fuel-N to NO under oxidizing atmosphere. When the temperature rises to above $1000^{\circ} \mathrm{C}$, calcium ferrite suppressed 
the conversion of fuel-N.

(3) Calcium ferrite begins to generate rapidly and in quantity when temperature is above $1000^{\circ} \mathrm{C}$. CF had a strong catalysis to the $\mathrm{CO}-\mathrm{NO}$ reaction. The speed of $\mathrm{CO}-\mathrm{NO}$ reaction accelerated and the $\mathrm{NO}$ degradation rate promoted with the increase of temperature. As a result, the conversion rate of fuel-N decreases with the increasing of temperature when heating granules.

\section{Acknowledgement}

The research was financially supported by the State Key Program of National Natural Science Foundation of China (No. U1660206), Natural Science Foundation of Hunan Province in China (No. 2015JJ3164), Opening Foundation of the Chinese National Engineering Research Center for Control and Treatment of Heavy metal Pollution, (No. 2015CNERC-CTHMP-14), Hunan Provincial Co-Innovation Center for Clean and Efficient Utilization of Strategic Metal Mineral Resources and Innovation Driven Plan of Central South University (No. 2015CX005), Hunan Provincial Innovation Foundation for Postgraduate (CX2016B054), Open-End Fund for the Valuable and Precision Instruments of Central South University (CSUZC201703).

\section{REFERENCES}

1) M. Abián, E. Peribáñez, Á. Millera, R. Bilbao and M. U. Alzueta: Combust. Flame, 161 (2014), 280.

2) O. Deschenes, M. Greenstone and J. S. Shapiro: SSRN Electron. J., 7557 (2013).

3) W. Q. Liu and Z. W. Wang: Technol. Eng. Appl., 11 (2014), 25 (in Chinese)

4) H. Hu, H. Huang, Z. W. Zeng, J. L. Zhang, S. Annanurov and Q. Z.
Zhao: Energy Sources Part A, 39 (2017), 1228.

5) D. Schlebusch, F. Cappel, J. Otto, F. Cappel, W. Gerlach, M. Hirsch, N. Magedanz, J. Otto and D. Schlebusch: Process for sintering iron oxide-containing materials on a sintering machine, U. S. Patent US 5476553A, (1995).

6) N. Hashimoto, H. Watanabe, R. Kurose and H. Shirai: Energy, 118 (2017), 47.

7) T. V. W. Janssens, H. Falsig, L. F. Lundegaard, P. N. R. Vennestr, S. B. Rasmussen, P. G. Moses, F. Giordanino, E. Borfecchia, K. A Lomachenko, C. Lamberti, S. Bordiga, A. Godiksen, S. Mossin and P. Beato: ACS Catal., 5 (2015), 2832.

8) Z. Yao: Chem. Biochem. Eng. Q., 29 (2016), 505.

9) W. Lv: Master thesis, Central South University, (2014), http://www. cnki.net/, (accessed 2014-06-27) (in Chinese).

10) Z. Zhao, W. Li, J. Qiu and B. Li: Fuel, 82 (2003), 1839.

11) Z. H. Wu, Y. Sugimoto and H. Kawashima: Fuel, 82 (2003), 2057.

12) N. Tsubouchi, Y. Ohshima, X. A. Chunbao and Y. Ohtsuka: Energy Fuels, 15 (2001), 158.

13) Y. G. Chen, Z. C. Guo and Z. Wang: ISIJ Int., 48 (2008), 1517.

14) E. Kasai, C. Xu, S. Wu and D. Cang: J. Soc. Mater. Eng. Resour. Jpn., 10 (1997), 62.

15) H. Liang, K. Gui and X. Zha: Can. J. Chem. Eng., 94 (2016), 1668.

16) K. Morioka, S. Inaba, M. Shimizu, K. Ano and T. Sugiyama: ISIJ Int., 40 (2000), 280.

17) X. H. Fan, Z. Y. Yu, M. Gan, X. L. Chen, Q. Chen, S. Liu and Y. S. Huang: ISIJ Int., 55 (2015), 2074.

18) K. Katayama and S. Kasama: ISIJ Int., 56 (2016), 1563.

19) D. Hirabayashi, T. Yoshikawa, K. Mochizuki, K. Suzuki and Y. Sakai: Catal. Lett., 110 (2006), 155.

20) J. Y. Fu, T. Jiang and D. Q. Zhu: Sintering and Pelleting, Central South University Press, Changsha, (1996), 142.

21) M. Gan, X. H. Fan, Z. Y. Ji, X. L. Chen, L. Yin, T. Jiang, G. H. Li and Z. Y. Yu: ISIJ Int., 55 (2015), 742.

22) X. Lv, C. Bai, Q. Deng, X. Huang and G. Qiu: ISIJ Int., 51 (2011), 722.

23) J. Zhang, X. M. Guo and X. J. Huang: J. Iron Steel Res. (Engl. ed.), 19 (2012), 1

24) M. Gan, X. H. Fan, W. Lv, X. L. Chen, Z. Y. Ji and T. Jiang: Powder Technol., 301 (2016), 478.

25) Z. Y. Ji, X. H. Fan, M. Gan, X. L. Chen, Q. Li and T. Jiang: Energy Fuels, 30 (2016), 10448.

26) Z. H. Wu, Y. Sugimoto and H. Kawashima: Fuel, 82 (2003), 2057. 